\title{
Performance of Algae Reactor for Nutrient and Organic Compound Removal
}

\author{
Agil Harnowo Putra, Aulia Ulfah Farahdiba ${ }^{1}$ \\ Department of Environmental Engineering \\ Universitas Pembangunan Nasional "Veteran" Jawa Timur \\ Surabaya, Indonesia \\ ${ }^{1}$ auliaulfah.tl@upnjatim.ac.id
}

\author{
Andik Yulianto, Muhammad Bintang Setyono, Wahyu \\ Arif Saputra \\ Department of Environmental Engineering \\ Universitas Islam Indonesia \\ Yogyakarta, Indonesia
}

\begin{abstract}
The excess content of nutrients in the water can cause eutrophication which has an impact on increasing turbidity and causing anoxic conditions in a waters. High Rate Algae Reactor (HRAR) is wastewater treatment and nutrient recycling based on symbiotic interactions between heterotropic bacteria and algae cells that live in waters. The aim of this research was to determine the efficiency of nutrient removal and the effect of aeration with the correlation of additional parameters. This research was implemented in a batches for 9 days with variations of aeration. Parameters analyzed were Chlorophyll-a, $\mathrm{COD}$, Nitrate $\left(\mathrm{NO}_{3}\right)$ and Phosphate $\left(\mathrm{PO}_{4}\right)$ as the main parameter whose analysis is conducted every 3 days and for additional parameters such as $\mathrm{DO}, \mathrm{pH}$, light also emperature are carried out every day. The results of the study show HRAR's ability to reduce nitrate $\left(\mathrm{NO}_{3}\right)$ and phosphate $\left(\mathrm{PO}_{4}\right)$, the best removal results on 24 -hour aeration are $43 \%$ and $38 \%$ with initial concentrations of $56.55 \mathrm{mg} / \mathrm{L}$ and $5.61 \mathrm{mg} / \mathrm{L}$. The greater the chlorophyll-a concentration (algae) in the reactor, the greater the level of removal efficiency in nutrients.
\end{abstract}

Keywords-Aeration; HRAR; Organic materials; Nutrient.

\section{INTRODUCTION}

In many metropolies, the problem of wastewater is constantly be the important problems. According to the Ministry of Environment (KLH) monitoring from 2008 to 2013, river water quality in almost 57 rivers in Indonesia concluded that around $70-75 \%$ of the rivers monitored were polluted. The pollution is lightly polluted, based on PP quality standards. 82 of 2001. Some wastewater produced by domestic and non-domestic activities has excess nutrient content so that the effect of this increase in nutrients can lead to uncontrolled eutrophication. Nitrogen and phosphorous are elements key to algal growth, they are also serious pollutants in many waterways. Algae can thrive in nitrogen- and phosphorus-rich conditions common to many wastewaters [1]. The impact of eutrophication is that it can lead an increase in turbidity and can lead anoxic conditions in these waters [2]. Nitrogen and phosphorus are the most influential nutrients for phytoplankton production [3]. High organic matter content in domestic wastewater increases pollution in the receiving water body. Increasing pollution can reduce public health. Increased pollution affects the lives of aquatic organisms and decreases the quality of water so that it is not in accordance with its demarkation. Several studies were carried out using algae as a bioremediation technology for wastewater treatment [4][5][6].

Algae and bacteria have a mutually beneficial relationship due to the limited $\mathrm{CO}_{2}$ and $\mathrm{O}_{2}$ needed for respiration of algae and bacteria. $\mathrm{CO}_{2}$ from bacteria is useful for the growth of algae and $\mathrm{O}_{2}$ from algae activity is useful for bacterial growth (Humenik and Hanna). Salah satu penerapan alga sebagai teknologi bioremediasi adalah dengan menggunakan HRAP (High Rate Algae Pond) [7][8]. High-Rate Algae Pond (HRAP) is defined as waste water treatment through nutrient recycling based on symbiotic interactions between heterotropic bacteria and algal cells that live in the pond [9]. High rate algal ponds (HRAPs) provide cost-effective and efficient wastewater treatment with minimal energy consumption and have considerable potential to upgrade oxidation ponds [8][10][11][12].

This research was conducted to determine the efficiency and optimum conditions of nutrient reduction (nitrate and phosphate), also organic material that is in wastewater with the ability of High Rate Algae Reactor (RAR) which is a replica of HRAP that uses algae as a bioremediation technology.

\section{RESEARCH METHODS}

\section{A. Research Material and Tools}

The equipment used for this research is needed to support the analysis, Samples of wastewater used as trial material are artifical wastewater samples, with equipment used namely DO meter to measure dissolved oxygen content, $\mathrm{pH}$ meter to measure acidity, lux meter to measure the level of light intensity, thermometer to measure temperature, spectrophotometer to measure the level of absorption, desiccator, aerator and HRAR reactor.

\section{B. Research Procedure}

This study will examine the effect of variation in duration of aeration on the ability of algae to absorb nutrients with HRAR systems for artificial wastewater treatment. The study was conducted in a laboratory scale.

Experiments were carried out with various aeration treatments, ie without aeration, 12 hours aeration and 24 hours 
aeration. aeration system using an aquarium pump. The parameters to be measured in this study are COD, DO concentration, $\mathrm{pH}$, light, and temperature as additional parameters are done every day. Measurement of chlorophyll-a, nitrate $\left(\mathrm{NO}_{3}\right)$ and phosphate $\left(\mathrm{PO}_{4}\right)$ as the main parameters are carried out every 3 days. The study was carried out a maximum of 9 days with variations in aeration time (with optimum conditions). However, research time can change according to the pattern of algal development. Before the research continued, seeding and acclimatization of algae was carried out to get healthy algae conditions. The reactor can be seen in Figure 1.

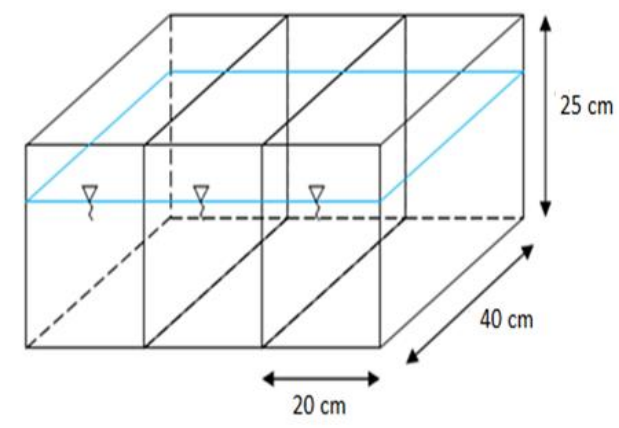

Fig. 1. HRAR Reactor

In this study, decreased nutrient nitrate $\left(\mathrm{NO}_{3}\right)$ and phosphate $\left(\mathrm{PO}_{4}\right)$ synthesis or wastewater was carried out using bioremediation. The level of water waste used in the research for nitrate is $50 \mathrm{mg} / \mathrm{L}$ and $5 \mathrm{mg} / \mathrm{L}$ for phosphate with a reactor volume of $10 \mathrm{~L}$, aeration time with three different variation.

Analysis of algae samples was carried out in the laboratory. Before running, testing for the most dominant algae classification using a microscope is carried out. Then the measurement method refers to table 1 .

TABLE I. MEASUREMENT METHOD

\begin{tabular}{|c|c|}
\hline Regulations & Measurement \\
\hline SNI 06-2412-1991 & Water quality sampling method \\
\hline SNI 06-2480-1991 & $\begin{array}{c}\text { The method of nitrate content test in } \\
\text { water by means of a spectrophotometer } \\
\text { with brucine sulfate }\end{array}$ \\
\hline SNI 06-2483-1991 & $\begin{array}{c}\text { The method of total orthophosphate and } \\
\text { phosphate test levels in water with a } \\
\text { spectrophotometer by ascorbic acid }\end{array}$ \\
\hline SNI 06-4157-1996 & $\begin{array}{c}\text { Test the levels of chlorophyll a } \\
\text { phytoplankton in water with a } \\
\text { spectrophotometer }\end{array}$ \\
\hline SNI 06-6989.14-2004 & $\begin{array}{c}\text { Water and wastewater, section 14- } \\
\text { yodometric method of dissolved oxygen } \\
\text { test }\end{array}$ \\
\hline SNI 06-6989.11-2004 & $\begin{array}{c}\text { Waste and wastewater, section 11- test } \\
\text { the degree of acidity by using a pH meter }\end{array}$ \\
\hline SNI 16-7062-2004 & $\begin{array}{c}\text { Measurement of the intensity of lighting } \\
\text { in the workplace }\end{array}$ \\
\hline
\end{tabular}

In table 1 it can be seen that the measurement of nitrate was carried out by referring to SNI 06-2480-1991 about the method of testing nitrate content in water by means of a spectrophotometer with brucine sulfate. Phosphate measurement was carried out by referring to SNI 06-2483-
1991 concerning the method of testing the total orthophosphate and phosphate levels in water with a spectrophotometer by ascorbic acid and for testing chlorophyll-a refers to SNI 06-4157-1996 about testing the levels of chlorophyll a phytoplankton in water with a spectrophotometer. In addition, additional parameters will use the DO meter, Lux meter and $\mathrm{pH}$ meter which has been calibrated.

\section{RESULTS AND DISCUSSION}

A. Characteristic of algae

Taking microscopic images of the whole settling chamber is neither necessary nor feasible, particularly when algal cell/colony numbers are high [13]. The algae seeds used in this research were obtained from fish ponds which were then analyzed the types that exist using a microscope. Observation results are the most dominant type of algae in the pond water. can be seen in Figure 2.

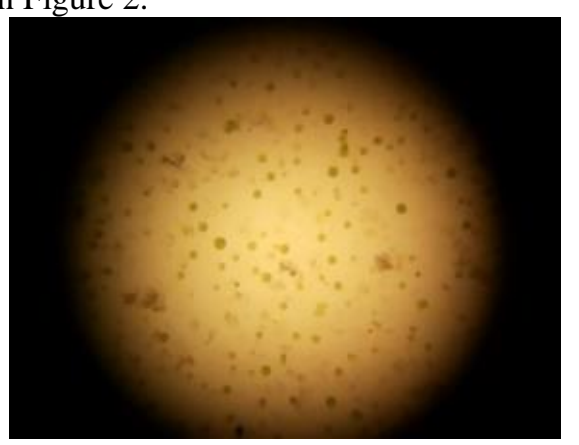

Fig. 2. Observation Results of Algae Enlargement

Based on the analysis using a microscope with a magnification of $100 x$, the characteristics of the dominant algae were found, namely the type of algae chlorella sp. This microalgae does not have true roots, stems and leaves, but has a chlorophyll pigment that is autotrophic. His body consists of unicellular and some are multicellular with properties that tend to form colonies. Chlorella-sp only reproduces asexual type, namely by mitotic type division. The cell reproduces by making two to eight cells contained in the stem cell and will be released if the environmental conditions support it.

\section{B. Chlorophyll Analysis}

Chlorophyll-a is the most common pigment in phytoplankton so phytoplankton concentration is often expressed in chlorophyll-a concentration [7]. These compounds that play a role in the process of photosynthesis of plants by absorbing and converting solar energy into chemical energy. The chlorophyll-a test results in this research can be seen in Figure 3.

On days 0 to 3 algae have entered the stationary phase, whereas on the 3rd to 9th days the algae enter the phase of death. The stationary phase of the algae is the phase where microalgae enter the limiting factor and the growth rate is equilibrium because the number of cells dividing and which die are the same, whereas the algae death phase is a phase where microalgae are no longer able to experience division. 


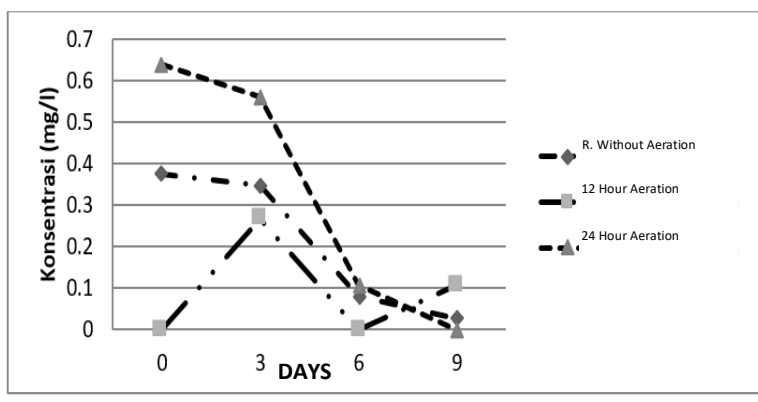

Fig. 3. Comparison of chlorophyll-a levels of each reactor

Algae death can be caused by several things. After the stationary phase the cell density has decreased which indicates that the culture has entered the phase of death and decreased cell density is also caused by the intensity of light that can be captured by cells in culture is reduced due to the increasingly dense cell population, when the light captured by Chlorella decreases, the rate of photosynthesis runs slowly, resulting in decreased cell growth.

\section{Decrease Organic Matter Analysis}

Wastewater that is loaded in organic matter is a good medium for growing microorganisms, because it contains various organic and inorganic substances that are essential to support the growth of microorganisms. Microorganisms play an important role in the elemental cycle through their ability to decompose and mineralize organic materials [14].

Bacteria use oxygen to process oxidizing organic matter. Measurement of the oxygen by bacteria to oxidize wastewater can also be referred to as the amount of concentration of organic matter present in wastewater, the results of these measurements can be expressed in COD and BOD. In this research the results of the measurement amount of oxygen needed in the oxidizing process of organic matter is expressed in the COD value. The results of the decrease in COD concentration using HRAR can be seen in Figure 4.

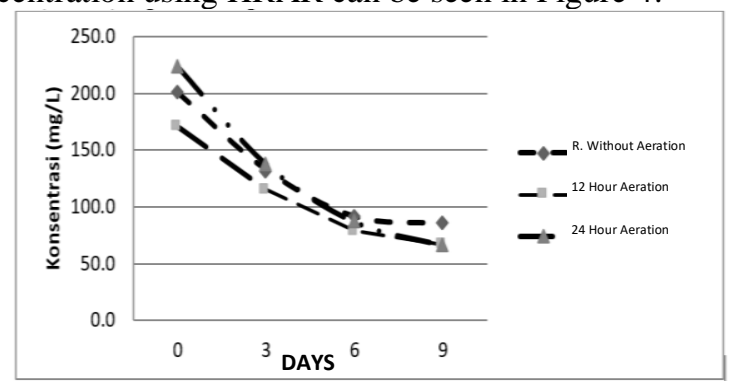

Fig. 4. COD concentration for each reactor

Initial COD concentrations differ from each other, especially in 12 hour aeration reactors which have specific differences. This is predicted to occur due to seeding and acclimatization, feeding in the form of sugar as carbon which is not organized in each reactor, so that the water in each reactor has a different COD concentration. Whereas for the percentage reduction in COD values can be seen in Figure 5.

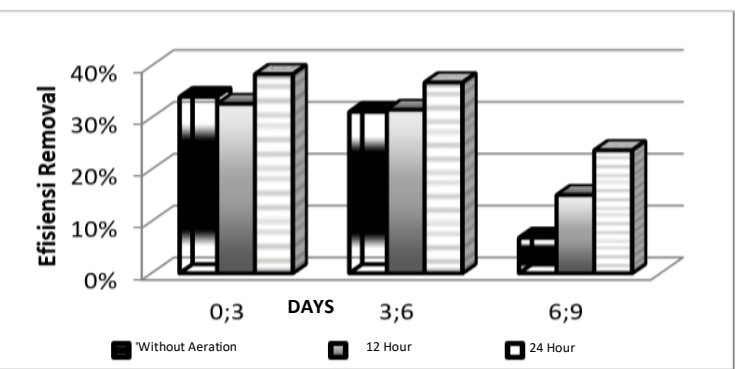

Fig. 5. Comparison of COD Removal Percentages

The highest decrease in COD concentration in the aeration reactor for 24 hours with an initial COD concentration of $223.250 \mathrm{mg} / \mathrm{L}$ and a final COD concentration of $66.3 \mathrm{mg} / \mathrm{L}$, the percentage of COD reduction reached $70 \%$, this is occur because the number of initial microorganisms in the reactor is more than other reactors and giving oxygen from an aerator for 24 hours, so that the growth of bacteria in the reactor is better than other reactors, causing the highest removal of the reactor. This is in accordance with the reference of [15] that the amount of degraded organic matter depends on the number of bacteria contained in the reactor and the availability of oxygen in the reactor.

D. Nitrate $\left(\mathrm{NO}_{3}\right)$ Analysis

Nitrate $\left(\mathrm{NO}_{3}\right)$ is the main form of nitrogen in natural waters and is a major nutrient for plant and algae growth. Nitrate nitrogen is very easily dissolved in water and stable. Absorption test of nitrate $\left(\mathrm{NO}_{3}\right)$ nutrients using $\mathrm{HRAR}$ and the results can be seen in Figure 6.

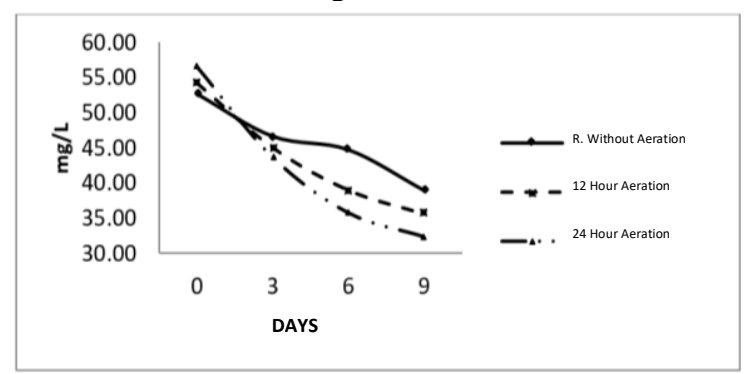

Fig. 6. Nitrate $\left(\mathrm{NO}_{3}\right)$ level for each reactor

Based on Figure 6 it is known that the reactor without aeration is the smallest efficiency reactor with a $26 \%$ reduction, where the initial concentration is $52.68 \mathrm{mg} / \mathrm{L}$ become $39.02 \mathrm{mg} / \mathrm{L}$. The efficiency of concentration reduction increases with the high levels of chlorophyll-a and the use of aeration, with the highest efficiency of $43 \%$ in 24 hours aeration treatment.

In addition to algae, bacteria also play a role in reducing nutrients. Reference to [16] that the form of nitrogen undergoes transformation (with or without involving microbiologists) as part of the nitrogen cycle.

The high and low levels of nitrate are related to the chlorophyll-a levels in each reactor. Nitrates become nutrients that play an important role in the growth of algae. At 12 hours and 24 hours aeration treatment has a percentage level with a downward trend adjusting to the level of algae. But the 
reactor with no aeration treatment from the 6th to the 9th day increases, this happens because nitrates that are not absorbed by plants experience denitrification and become free nitrogen $\left(\mathrm{N}_{2}\right)$ or nitrous oxide $\left(\mathrm{N}_{2} \mathrm{O}\right)$, when the oxygen concentration is reduced in the pool of water, the denitrification process takes over the nitrification process [17].

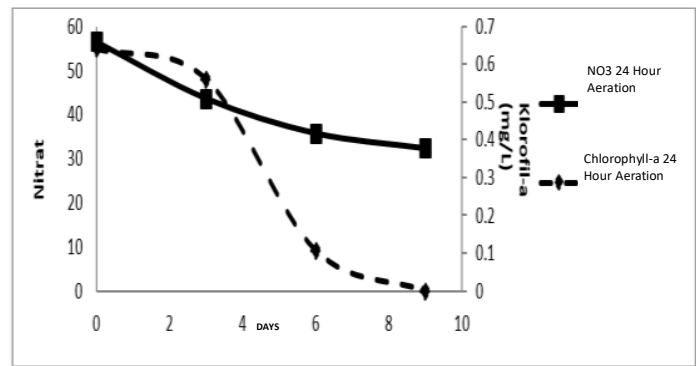

Fig. 7. Nitrate (NO3) Correlation with Chlorophyll-a in 24 hour aeration reactor

Figure 7 explains that the reactor with 24-hour aeration treatment has removal efficiency that adjusts to the rate of reduction of chlorophyll-a the percentage of nitrate removal efficiency decreased every 3 days. This can occur because the chlorophyll-a (algae) content which is in the condition of the aeration reactor 24 hours every 3 days also decreases. The correlation between nitrate and chlorophyll-a based on the calculation obtained a positive correlation with a value of 0.917 .

\section{E. Phosphate $\left(\mathrm{PO}_{4}\right)$ Analysis}

Phosphates in the waters are in various forms, including in the form of calcium phosphate granules $\left(\mathrm{CaPO}_{4}\right)$ and iron phosphate $\left(\mathrm{FePO}_{4}\right)$ and some in the form of inorganic phosphate (orthophosphat). The optimal phosphate content for phytoplankton growth is in the range of 0.27 to $5.51 \mathrm{ppm}$ [36]. The results of phosphate level testing (PO4) at each reactor can be seen in Figure 8.

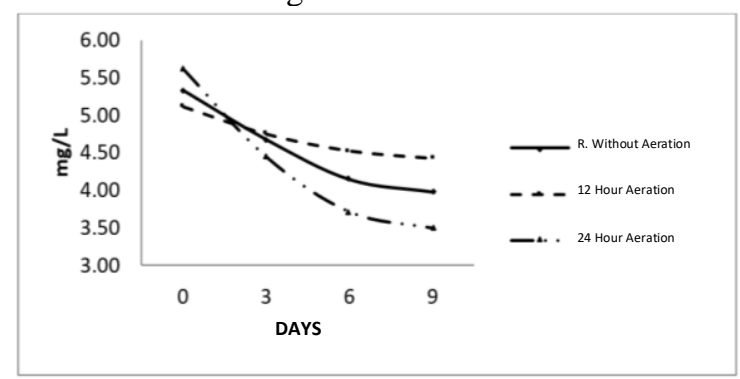

Fig. 8. Phosphate levels $\left(\mathrm{PO}_{4}\right)$ for each reactor

Figure 8. shows that the phosphate concentration $\left(\mathrm{PO}_{4}\right)$ in the reactor with 24 hour aeration treatment has the highest efficiency level of $38 \%$ where the phosphate concentration dropped from $5.61 \mathrm{mg} / \mathrm{L}$ to $3.49 \mathrm{mg} / \mathrm{L}$. While the smallest efficiency of phosphate concentration is in the reactor with 12 hours of aeration at night which is $14 \%$, where the phosphate concentration drops from an initial value of $5.11 \mathrm{mg} / \mathrm{L}$ to 4.42 $\mathrm{mg} / \mathrm{L}$.

The decrease in phosphate concentration occurred from day 0 to day- 9 in each treatment, the biggest decrease occurred on day 0 to day 3 , this is occur on day 0 to day 3 the concentration of algae is still high so there is a large decrease compared to the day after. This is consistent with reference [36] that on the surface of water, phosphate is transported by phytoplankton with photosynthesis.

Correlation analysis is also carried out between phosphate and chlorophyll-a to determine the ability of algae to absorb phosphate. Correlation can be seen in Figure 99.

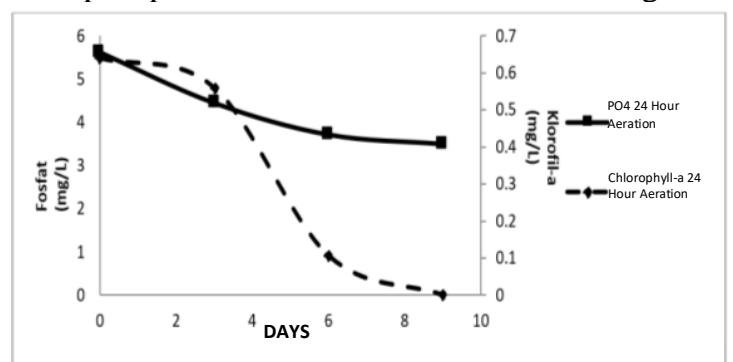

Fig. 9. Phosphate $\left(\mathrm{PO}_{4}\right)$ correlation with chlorophyll-a in the 24 hour aeration reactor

Phosphate concentration removal efficiency $\left(\mathrm{PO}_{4}\right)$ in the reactor with aeration treatment 24 hours every 3 days experienced a decrease seen in Figure 9, The decrease in phosphate concentration removal efficiency adjusts to the decrease in chlorophyll-a (algae) levels in the reactor. In addition, from the correlation chart it can also be seen that the efficiency of phosphate reduction is more dominantly carried out by algae compared to bacteria. The correlation between nitrate and chlorophyll-a based on calculations obtained the correlation value of 0.911 with a positive mark.

\section{F. Water Quality Analysis}

This water quality parameter data is obtained from sampling conducted twice a day, which is at $08.00 \mathrm{AM}$ and 15.00 PM. The parameters tested are $\mathrm{pH}, \mathrm{DO}$, temperature and light to determine the correlation between algae and other parameters.

1) Dissolved Oxygen (DO)

DO is one of the water quality parameters that is important for the survival of an organism in an aquatic environment. The DO measurement function is to determine the availability of oxygen in a waters for the respiration process. The results of DO wastewater measurements at each reactor can be seen in Fig

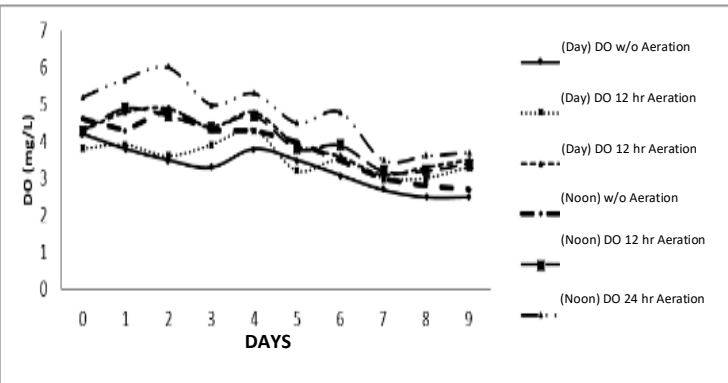

Fig. 10. Results of DO morning \& afternoon test for each reactor 
The average measurement results of DO values have decreased from the beginning of the research until the end of the research. The biggest value of DO in the study was on day 2 of the 24 hour aeration reactor which was $6 \mathrm{mg} / \mathrm{L}$ and the lowest was on the day- 9 aeration without reactor with a value of $2.5 \mathrm{mg} / \mathrm{L}$. Decrease in dissolved oxygen levels associated with microbial processes that are formed and the overhaul of organic materials in the waters.

The level of dissolved oxygen in a pond can experience sudden changes due to the influence of the decomposition of organic matter, breathing and decay in pond water so that it can cause oxygen depletion. Meanwhile, reference to [1] DO describes the dissolved oxygen content contained in a waters, sources of input of dissolved oxygen in the waters can come from air diffusion and photosynthesis. Correlation analysis was also carried out between DO and chlorophyll-a to determine the ability of algae to produce oxygen. The relationship between DO and chlorophyll-a can be seen in Figure 11.

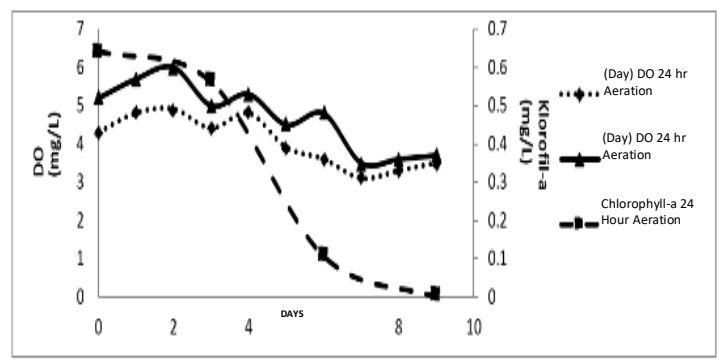

Fig. 11. DO correlation with Chlorophyll-a at 24 hours reactor

Chlorophyll-a correlation shows the amount of algae to DO in the reactor. This value is in accordance with the level of abundance of phytoplankton (algae), where the abundance of high phytoplankton produces more oxygen than the abundance of lower phytoplankton. This happens because dissolved oxygen is the production of photosynthesis. The correlation between DO and chlorophyll-a based on calculations obtained a correlation value of 0.825 with a positive mark.

2) $\mathrm{pH}$

The $\mathrm{pH}$ value represents the value of the concentration of hydrogen ions in a solution. The ability of water to bind and release a number of hydrogen ions will indicate whether the solution is acidic or alkaline. The $\mathrm{pH}$ measurement results can be seen in Figure 12.

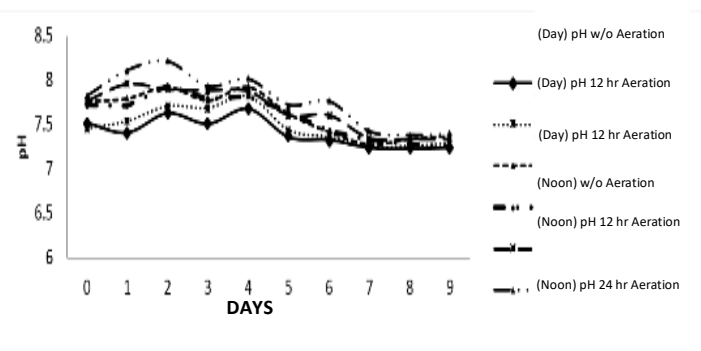

Fig. 12. Day and noon $\mathrm{pH}$ test results for each reactor
Figure 12. shows the average $\mathrm{pH}$ value in the range 7-8. A good $\mathrm{pH}$ for the growth of green algae and brown algae ranges from 6 to 9 . Some types of algae are tolerant to such $\mathrm{pH}$ conditions [3].

Changes in the $\mathrm{pH}$ of a waters affect the solubility of oxygen (DO). The higher $\mathrm{pH}$ value in a waters, it affect to dissolved oxygen value in the waters. Correlation analysis is carried out between $\mathrm{pH}$ and DO to strengthen the relationship between parameters, as shown in Figure 13.

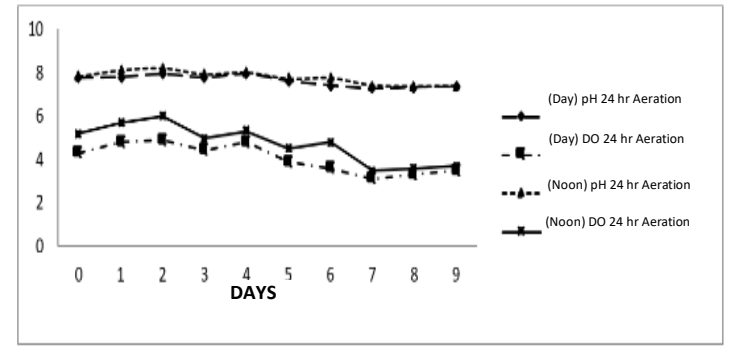

Fig. 13. pH correlation with DO at 24 hours reactor

Figure 13 shows that the $\mathrm{pH}$ value adjusts to DO concentration, this occur because the photosynthesis process from algae is the process of changing inorganic compounds into organic compounds with the help of sunlight, In addition, this can be found if a number of carbon fixed by autotrophic organisms through the synthesis of organic substances from inorganic compounds such as $\mathrm{CO}_{2}$ and $\mathrm{H}_{2} \mathrm{O}$. Synthesis in this process uses energy from solar radiation or a small portion through chemical reactions. So that $\mathrm{CO}_{2}$ solubility decreases and $\mathrm{O}_{2}$ increases. The correlation between $\mathrm{DO}$ and $\mathrm{pH}$ based on calculations obtained a correlation value of 0.984 with a positive mark.

3) Light

Light is very important because it is closely related to photosynthesis which occurs in the waters naturally. Brightness shows the extent to which light of a certain intensity can penetrate the depth of the waters. Of the total sunlight that falls into the atmosphere and earth, only less than $1 \%$ is captured by chlorophyll (on land and water), which is used for photosynthesis [2]. Here are the results of measuring the intensity of light in each reactor.

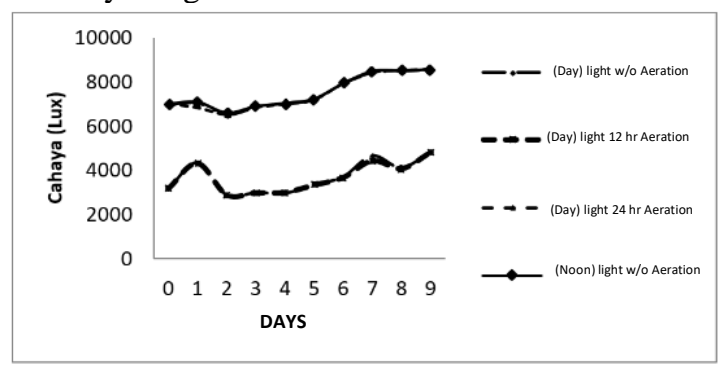

Fig. 14. Results of test between day and noon light of each reactor 
The intensity of light at each reactor is not much different seen in the picture the average intensity value in the morning is 3000-5000 lux while during the day the intensity value of 6000-9000 lux. Reference to [14], the intensity of light needed for photosynthesis ranges from 500-10,000 lux, so that the light intensity in this research at the optimum condition of algae in photosynthesis.

Correlation analysis between light and temperature is also done to determine the level of attachment between parameters, as described in Figure 15.

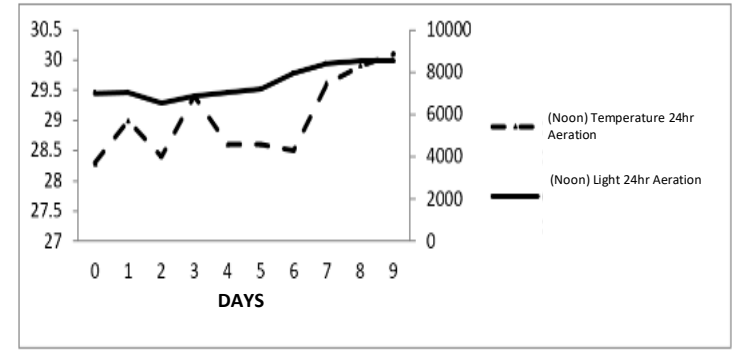

Fig. 15. Correlation between light and temperature ath the 24 hours reactor

Figure 15 shows that the increase in temperature from the first day to the last day adjusts to the level of light intensity in the reactor. Rays that enters the waters will experience absorption and change into heat energy thus increasing the water temperature [5]. The correlation between temperature and light based on calculations obtained a correlation value of 0.735 with a positive mark. Correlation analysis is also carried out between light and do. correlation can be seen in Figure 16.

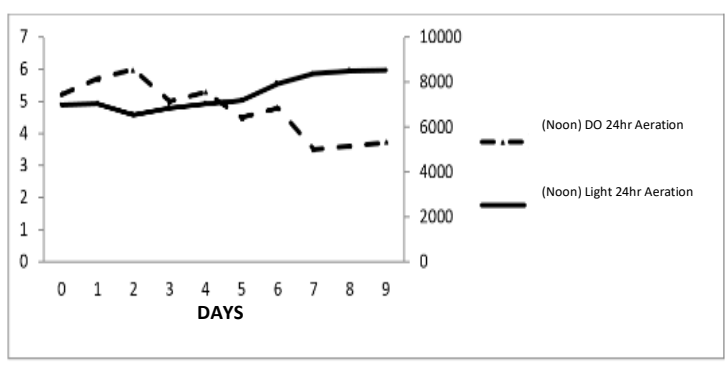

Fig. 16. Light \& DO correlation at 24 hours reactor

Figure 16 shows that the DO value from the first day to the last day decreases while the light intensity in the reactor increases. This occur because the increase in light intensity is directly proportional to the temperature of the water in the reactor. So that if the temperature of the water rises it will cause some consequences, one of which is the amount of dissolved oxygen in the water decreases [6]. Besides that the descent in DO is also caused by the death of algae in the reactor so that dissolved oxygen is no longer produced by algae. The correlation between DO and light based on calculations obtained a correlation value of -0.916 with a negative mark.

4) Temperature
The temperature measured in this research is the temperature of the wastewater in each reactor. Temperature fluctuations happens due to differences in light intensity and biological processes that occur in the reactor, day 0 to day 9. Observation of the temperature of the waste water in the reactor can be seen in Figure 17.

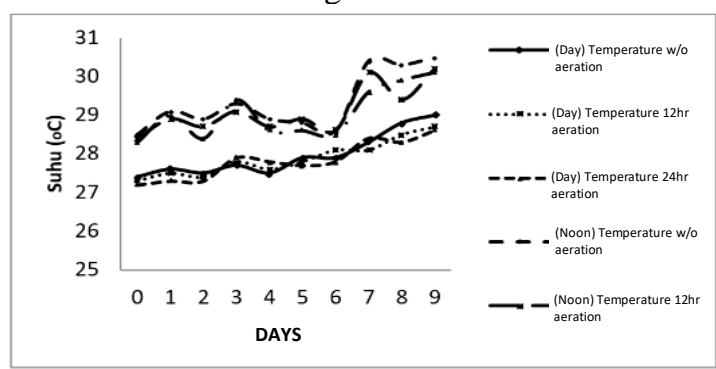

Fig. 17. Temperature test day and noon of each reactor

Observations show that the difference in daily temperature has a value that tends to be the same. The range of average temperature values in the morning is $27-29{ }^{0} \mathrm{C}$ while the temperature range during the day is in the range of $28-30{ }^{\circ} \mathrm{C}$. The average water temperature ranges from $24-32{ }^{\circ} \mathrm{C}$ so that in this range, plankton can grow and reproduce well [11].

\section{IV.CONCLUSION}

Based from the results of research and discussion conducted, then got the following conclusion:

1. The results of the study show HRAR's ability to reduce nitrate (NO3) and phosphate (PO4), the treatment without aeration removal efficiency was $26 \%$ and $25 \%$ with initial concentrations of $52.68 \mathrm{mg} / \mathrm{L}$ and $5.33 \mathrm{mg} / \mathrm{L}$, in aeration treatment 12 hours at night removal efficiency was $34 \%$ and $14 \%$ with initial concentration of $54.18 \mathrm{mg} / \mathrm{L}$ and 5.11 $\mathrm{mg} / \mathrm{L}$ and the best treatmen occur at 24-hour aeration is $43 \%$ and $38 \%$ with initial concentrations of $56.55 \mathrm{mg} / \mathrm{L}$ and $5.61 \mathrm{mg} / \mathrm{L}$.

2. HRAR is able to reduce the levels of organic matter which in the study are expressed in COD concentrations. The best COD reduction efficiency was $70 \%$ with an initial concentration of $223.3 \mathrm{mg} / \mathrm{L}$ and the end of 66.3 $\mathrm{mg} / \mathrm{L}$. HRAR with other treatments has less efficiency. The value of COD efficiency without aeration is $58 \%$ and 12 hours aeration is $61 \%$ with the initial concentration of each reactor is $200.8 \mathrm{mg} / \mathrm{L}$ and $170.8 \mathrm{mg} / \mathrm{L}$ and the final concentration is $85 \mathrm{mg} / \mathrm{L}$ and $66.9 \mathrm{mg} / \mathrm{L}$.

3. Aeration affects the availability of dissolved oxygen (DO) in the reactor and DO affects various biological processes that occur in the water, such as the process of algae and bacterial respiration in the reactor, bacterial activity in degrading nutrients and maintaining acidity $(\mathrm{pH})$ of water. So that the 24 hour aeration reactor is better at removal nutrient.

4. Light acts as energy for algae photosynthesis to produce $\mathrm{O}_{2}$, the more $\mathrm{O}_{2}$ dissolved in water the greater the DO 
value. Besides that, ligt also plays a role in temperature fluctuations and solubility of oxygen in water. Correlation of DO parameters, $\mathrm{pH}$, temperature and light to the ability of algae to absorb nutrients has a large relationship with the average correlation approaching 1 (one) with a very strong relationship.

5. Giving air $(\mathrm{O} 2)$ manually (aeration) is influential on the performance of bacteria to degrade organic matter.

6. The number of microorganisms affects the removal efficiency of decreasing COD concentration.

\section{RECOMMENDATION}

Based on the conclusion of the research above, the suggestion that can be submitted for further research :

1. Further research can be used for original wastewater so that it can be applied directly to the testing of waste nutrients from agriculture or domestic.

2. It is necessary to have an analysis in advance to find out the microorganisms in the research reactor, so that the degradation process that occurs in each of them is accurately known by algae or by bacteria.

\section{REFERENCES}

[1] J. Rimper, "Kelimpahan Phytoplankton Dan Kondisi Hydroseanografi Perairan Teluk Manado,” Bogor: Institut Pertanian Bogor, unpublished, 2002.

[2] C.F. Mason, "Biology of Freshwater Pollution," Second Edition, New York: Longman and Scientific and Technical, 1993.

[3] I. Roshisati, "Distribusi spasial biomassa fitoplankton (klorofil-a) di perairan Teluk Lampung pada bulan Mei, Juli, dan September 2001," Undergraduate Thesis. Bogor: Institut Pertanian Bogor, unpublished, 2002 .
[4] I. de Godos, S. Blanco, P.A. Garcia-Encina, E. Becares, and R. Munoz, "Long term operation of high rate algal ponds for the bioremediation of piggery wastewaters at high loading rates," Bioresource Technol., vol.100, pp. 4332-4339, 2009.

[5] D.M. Mahapatra, H.N. Chanakya, and T.V. Ramachandra, "Bioremediation and lipid synthesis through Myxotrophic Algal Consortia in Municipal Wastewater" Bioresource Technol., vol.168, pp. 142-150, 2014.

[6] G. Sivakumar, J. Xu, R.W. Thompson, Y. Yang, P. Randol-Smith, and P.J. Weathers, "Integrated green algal technology for bioremediation and biofuel," Bioresource Technol., vol. 107, pp. 1-9, 2012.

[7] J.B.K. Park, R.J. Craggs, and Shilton, "Recycling alga to improve species control and harvest efficiency from a high rate algal pond," Water Res., vol.45, pp. 6637-6649, 2011.

[8] T.R. Parsons, M. Takeshi, and B. Hagrave, Biological oceanographic proscsses, Third Edition, Oxford: Pergamon press, 1968.

[9] W.J. Oswald and C.G. Golueke, Large Scale Production of Algae, 1968.

[10] R.J. Craggs, R.J. Davies-Colley, C.C. Tanner, and J.P.S Sukias, "Advanced ponds systems: performance with high rate ponds of different depths and areas, "Water Sci. Technol., vol. 48, pp. 259-267, 2003.

[11] J. Garcia, B.F. Green, T. Lundquist, R. Mujeriego, M. HernandezMarine, and W.J. Oswald, "Long term diurnal variations in contaminant removal in high rate ponds treating urban wastewater," Bioresource Technol., vol. 97, pp. 1709-1715, 2006.

[12] S. Heubeck, R.J. Craggs, and A. Shilton, "Influence of $\mathrm{CO} 2$ scrubbing frombiogas on the treatment performance of a high rate algal pond," Water Sci. and Technol., vol. 55, pp. 193, 2007.

[13] K.A. Safi, "Algal Services Methods: Standard Operating Procedure 2.0 Version 4.0.," Auckland: NIWA Algal Services Laboratory, 2009.

[14] M. Kawaroe, T. Prartono, A. Sanuddin, D. Wulansari, and D. Augustine, Mikroalga : Produksi dan pemanfaatan untuk Bio Bahan bakar, Bogor: IPB Press, 2010

[15] F.J. Humenik, and G.P. Hanna, "Algal-Bacterial Symbiosis Forremoval and Conservation of Waste-Water Nutrients," J. Water Pollut. Control Fed., vol. 43, pp. 580-593, 1971

[16] H. Effendi, "Telaah Kualitas Air : Bagi Pengelolaan Sumberdaya dan Lingkungan Perairan,” Bogor: Institut Pertanian Bogor, 2003.

[17] V. Novotny and H. Olem, Water Quality, Prevention, Identification, and Management of Diffuse Pollution, New York: Van Nostrand Reinhold, 1994. 